https://doi.org/10.11646/zootaxa.4254.1.8

http://zoobank.org/urn:lsid:zoobank.org:pub:7950D70D-1260-41F2-B4A6-CE6BB0EC8D45

\title{
A new groundwater-dwelling species of Euryrhynchina from Cameroon (Malacostraca, Decapoda, Euryrhynchidae)
}

\author{
SAMMY DE GRAVE ${ }^{1}$, CHRISTOPHE PISCART ${ }^{2}$, RAOUL P. TUEKAM KAYO ${ }^{3} \&$ ARTHUR ANKER $^{4}$ \\ ${ }^{\prime}$ Oxford University Museum of Natural History, Parks Road, Oxford, OXI 3PW, United Kingdom. \\ E-mail: sammydegrave@oum.ox.ac.uk \\ ${ }^{2}$ UMR CNRS 6553-ECOBIO, Campus de Beaulieu - Bat 14A, 263 Avenue du Général Leclerc, F-35042 Rennes Cedex, France \\ ${ }^{3}$ University of Yaoundé 1 Laboratory of General Biology, Faculty of Science. P.O. BOX. 812 Yaounde, Cameroon. \\ ${ }^{4}$ Universidade Federal de Goiás, Instituto de Ciências Biológicas, Avenida Esperança s/n, Campus Samambaia - Prédio ICB5, CEP \\ 74690-900, Goiânia, GO, Brazil
}

\begin{abstract}
A new species of the euryrhynchid shrimp genus Euryrhynchina Powell, 1976, E. puteola sp. nov., is described from Cameroon. The new species can be easily distinguished from the only other species in the genus, E. edingtonae Powell, 1976, by the absence of a setiferous lobe on the eye peduncle, the absence of a meral spine on the ambulatory pereiopods, the shape of the scaphocerite tooth, a single spine on the uropodal diaeresis (vs. 2-3), the absence of a podobranch on the second maxilliped, and the absence of appendices internae on the male pleopods 2-5. Although the species was discovered in a phreatic well, it remains unclear if it is a true stygobiont.
\end{abstract}

Key words: Afrotropical region, freshwater shrimp, new species, West Africa

\section{Introduction}

The freshwater caridean shrimp family Euryrhynchidae Holthuis, 1950 currently comprises three genera. The type genus, Euryrhynchus Miers, 1877, presently contains five species distributed in northern South America, from Venezuela in the north to the Brazilian state of Rondônia in the south (Pachelle \& Tavares, pers. comm.), and from Pará in the east to the upper Amazon region of Peru in the west (De Grave 2007). The West African genera of the family, Euryrhynchina Powell, 1976 and Euryrhynchoides Powell, 1976, are each monotypic and are far less known than their South American counterpart, with almost all taxonomic information about them being concentrated in their original descriptions (Powell, 1976).

Euryrhynchina was established by Powell (1976) for E. edingtonae Powell, 1976 from a swamp forest along the Ogba River, south-west of Benin City centre, southern Nigeria. This species lives in slow-flowing surface water throughout the western half of the Niger Delta (Powell 1976; Victor \& Ogbeibu 1985; Ikomi et al. 2005), including seasonally flooded wetlands (Olomukoro \& Dirisu 2014), but does not occur in reservoirs (Ogbeibu \& Oribhabor 2002). Based on limited work, E. edingtonae appears to be moderately tolerant of human recreational activities (Ikomi \& Arimoro 2014), but does not occur in waters frequently disturbed by larger boat traffic and/or localised pollution (Olomukoro 2009).

The present study reports a new species of Euryrhynchina based on material collected from a well in southeastern Cameroon, representing the second species in the genus and the first record of the genus outside of Nigeria.

\section{Material and methods}

Sampling was performed in several wells in the city of Mbanga in southeastern Cameroon in 2012. Faunal samples were taken from the bottom of five wells using a modified phreatic net, as originally described by Cvetkov (1968). The net sampler had a diameter of $30 \mathrm{~cm}$ and a mesh size of $64 \mu \mathrm{m}$. 
The climate of the area can be characterised as a subequatorial oceanic climate with a shorter dry season extending from mid-November to January and a longer rainy season extending from January to mid-November. The humidity of the air is around $85 \%$ with minor variations in temperature $\left(27-30^{\circ} \mathrm{C}\right)$ and abundant monthly precipitation (2500-3000 mm) (CVUC-UCCC 2014).

The dominant soil type in the area is a yellow ferralitic soil due to the crystalline plinth, sometimes overlayered by volcanic soils. The amount of clay is important in this type of soil linked to its water retention capacity. The ferralitic soil generally leads to the formation of small superficial aquifers (Segalen 1985), which are abundant in the area.

Asides from faunal samples in each well, water samples were also collected. In the field, direct measurements were made of temperature, $\mathrm{pH}$, electrical conductivity, TDS and dissolved oxygen, respectively, with a $1 / 10^{\circ} \mathrm{C}$ mercury thermometer, a portable $\mathrm{pH}$-meter (CG 818, Schott instruments ${ }^{\mathrm{TM}}$ ), and a portable Conductimeter / TDSmeter / Optical dissolved oxygen meter (HQ30d, Hach Lange ${ }^{\mathrm{TM}}$ ). Other measurements were made in the laboratory of University of Yaoundé 1 (Yaoundé) from water samples directly poured into polyethylene bottles without generating bubbles. These bottles were cool transported to the laboratory for analysis, and thoroughly shaken before measurements. Alkalinity, dissolved carbonic gas and calcic hardness were measured using the volumetric method, following Rodier et al. (2009) recommendations. In addition to the physico-chemical characteristics of well water, several measures were made to characterise physical dimensions of the wells, including the height of the margin, presence/absence of covers (wells open or closed), well diameter, total depth of the well, level of the water, as well as the piezometric level, as all these parameters may have an influence on the presence of groundwater fauna in the well (Nana Nkemegni et al. 2015).

Type material is deposited in the Zoological Collections of the Oxford University Museum of Natural History, Oxford, United Kingdom (OUMNH.ZC), and the Muséum National d'Histoire Naturelle, Paris, France (MNHN$\mathrm{IU})$. Carapace length ( $\mathrm{cl}$, in $\mathrm{mm}$ ) was measured from the tip of the rostrum to the posterior margin of the carapace.

\section{Systematics}

\section{Order Decapoda Latreille, 1802}

Infraorder Caridea Dana, 1852

Family Euryrhynchidae Holthuis, 1950

\section{Euryrhynchina Powell, 1976}

\section{Euryrhynchina puteola sp. nov.}

(Figs. 1-3)

Material examined. Holotype. CAMEROON: $1 \sigma^{\hat{\alpha}}(\mathrm{cl} \mathrm{1.8)}$, small well used for drinking water, behind the Gendarmerie, Quartier II of Mbanga city, Littoral Province, $04^{\circ} 29^{\prime} 50^{\prime} \mathrm{N}$ 09³3'45”E, $0.67 \mathrm{~m}$ wide, depth $9.5 \mathrm{~m}$, water level (piezometric level) at $7.3 \mathrm{~m}$ with $2.2 \mathrm{~m}$ of water depth, leg. R.P. Tuekam Kayo, 20.i.2012 (OUMNH.ZC.2016-05-001). Paratypes. $4 \hat{\partial}(\mathrm{cl} 2.7,1.7,2.8,1.8)$, same data as for holotype (OUMNH.ZC.201605-002 to 2016-05-005); $2 \widehat{\partial} \sigma^{\lambda}$ (cl 1.9, 2.1), 1 spec., sex unknown (cl 1.4) (MNHN-IU-2014-19519).

Description. Carapace smooth, without setae, branchiostegial groove barely visible; rostrum triangular in shape, falling short of distal margin of eyes (Fig. 1A, B); suborbital angle poorly developed, antennal spine absent; pterygostomial angle protruding forward, triangular, overreaching rostrum (Fig. 1B).

Pleon smooth, pleura 1-3 ventrally rounded, pleura 4-5 with postero-lateral angle somewhat quadrate.

Eyes (Fig. 1A, B) reduced, pigmented cornea small, facets poorly if at all developed; anteromesial margin of peduncle not produced, without setae.

Antennular peduncle with stylocerite not laterally expanded (Fig. 1D); anterolateral angle of basal article produced into sharp tooth, reaching to mid-length of second article; second article short, anterolateral and anteromesial angles bluntly produced; three antennular flagella present, entirely free throughout their lengths, middle flagellum consisting of five articles, ultimate twice as long as penultimate, aesthetascs only present on distal article. 
Antennal scaphocerite broad, slightly longer than antennular peduncle (Fig. 1A); lateral margin straight, ending in stout sharp distal tooth, latter shorter than distal margin of lamella (Fig. 1E).

Mandible with incisor and molar processes widely separated (Fig. 2A), palp absent; incisor process ending in four equally sized teeth; molar process weakly bilobed. Maxillule (Fig. 2B) with two endites, palp distally bilobed. Maxilla (Fig. 2C, D) with single endite, endopod short, proximally broadening; scaphognathite large. First maxilliped (Fig. 2E) with broad caridean lobe, epipod present. Second maxilliped (Fig. 2F) without podobranch. Third maxilliped (Fig. 2G) without arthrobranch or pleurobranch.
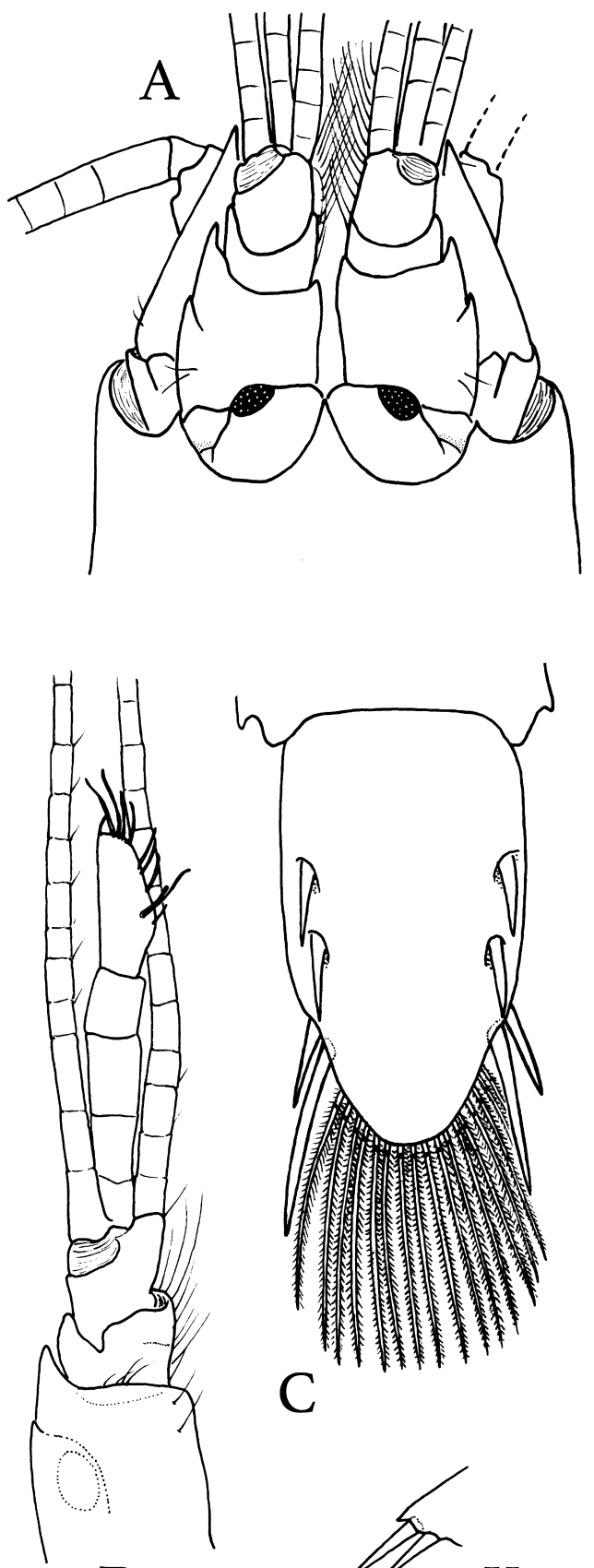

$\mathrm{D}$
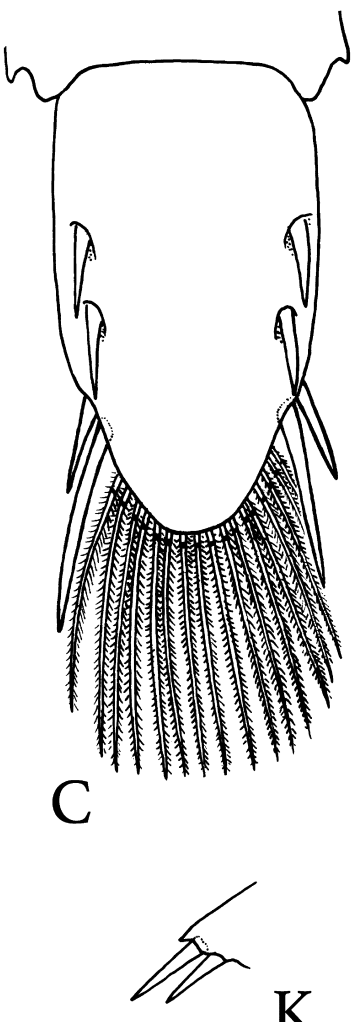
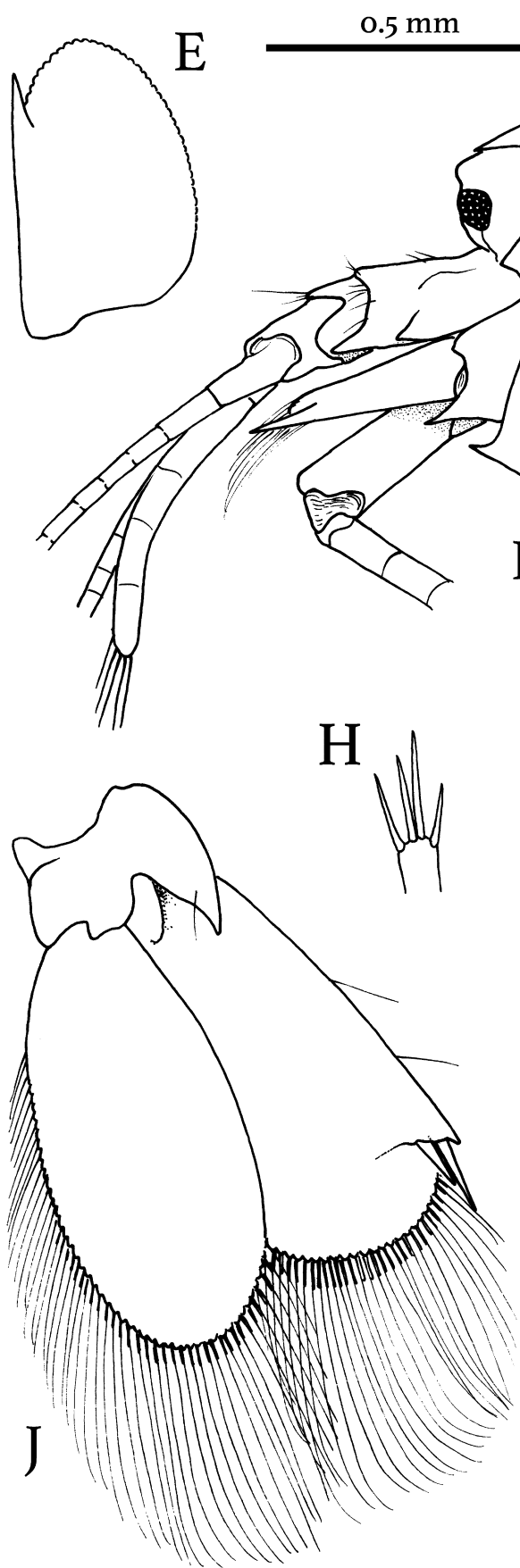

FIGURE 1. Euryrhynchina puteola sp. nov. A) frontal region, dorsal view; B) same, lateral view; C) telson, dorsal view; D) antennule, dorsal view; E) scaphocerite, dorsal view; F) first pleopod, ventral view; G) second pleopod, ventral view; H) same, detail of appendix masculina; I) third pleopod, dorsal view; J) right uropod, dorsal view; K) left uropod, distal part of diaeresis, dorsal view. Holotype, male, OUMNH.ZC.2016-05-001 (cl 1.8) (A-C); paratype, male, OUMNH.ZC.2016-05-005 (cl 1.8) (DJ); paratype, male, OUMNH.ZC.2016-05-004 (cl 2.7) (K). Scale bar as indicated, except H (drawn without scale). 


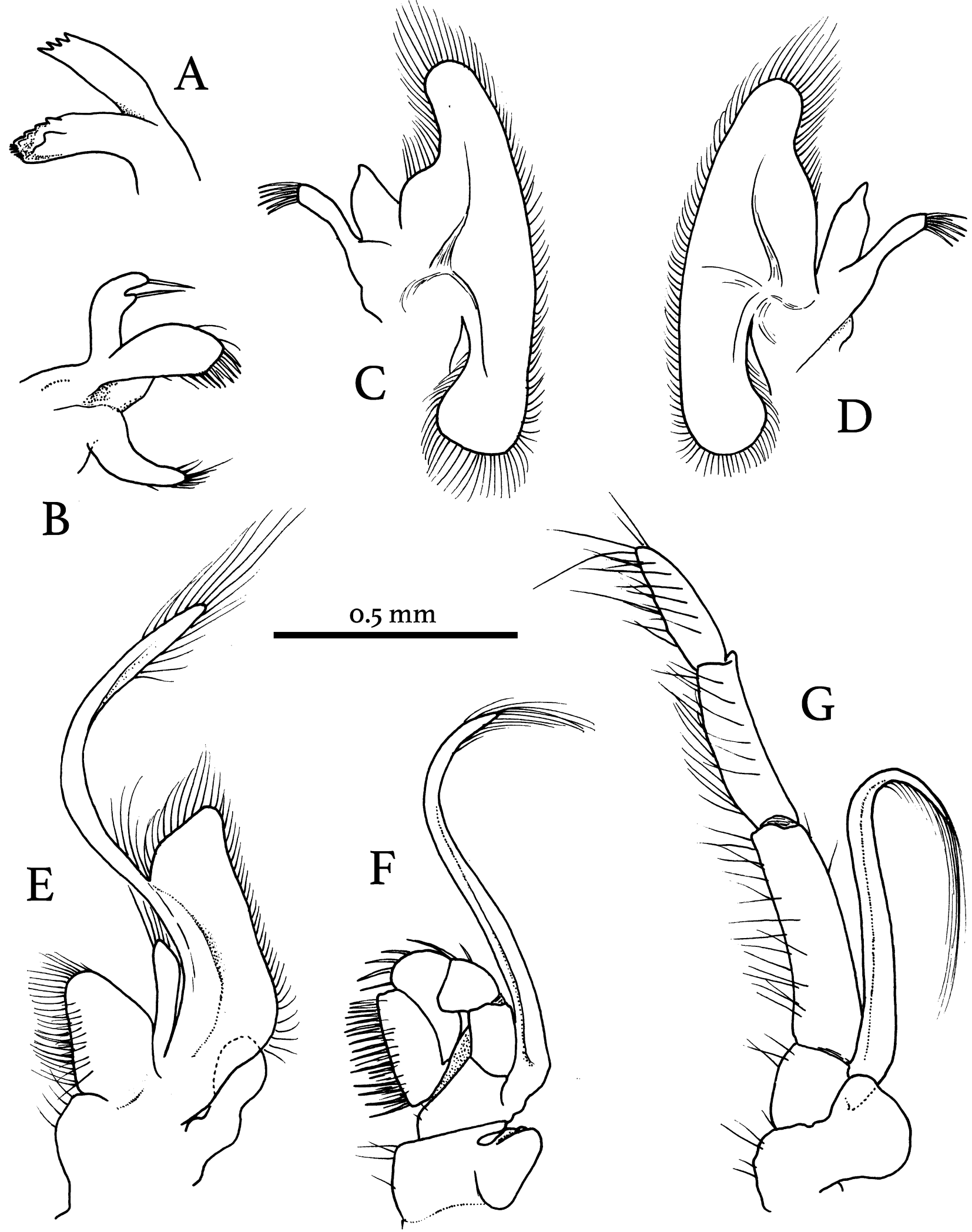

FIGURE 2. Euryrhynchina puteola sp. nov. A) mandible, mesial view; B) maxillule, lateral view; C) maxilla, lateral view; D) same, mesial view; E) first maxilliped, lateral view; F) second maxilliped, lateral view; G) third maxilliped, lateral view. All from paratype, male, OUMNH.ZC.2016-05-005 (cl 1.8) 


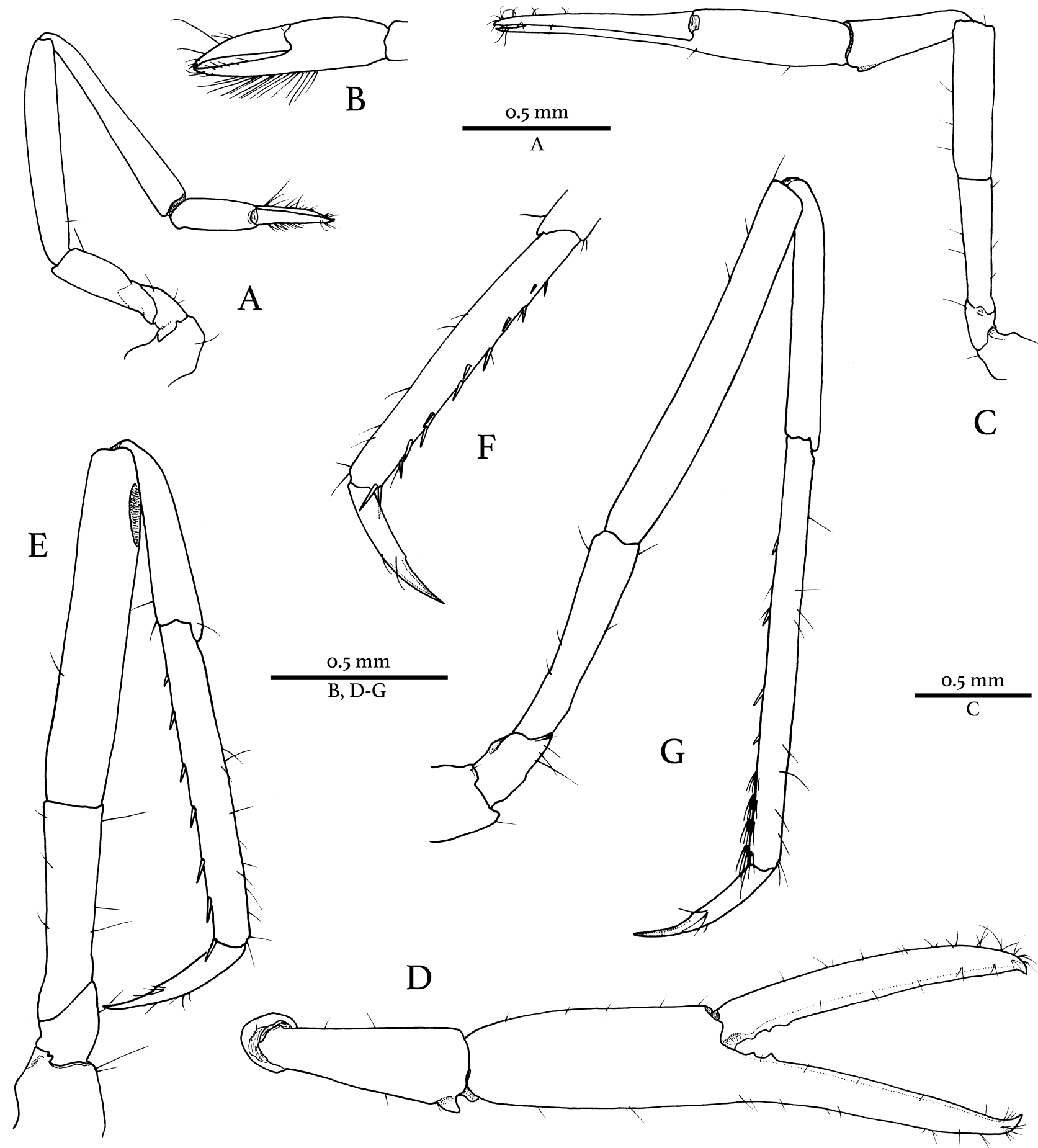

FIGURE 3. Euryrhynchina puteola sp. nov. A) first pereiopod, lateral view; B) same, detail of chela, mesial view; C) second pereiopod, lateral view; D) same, carpus and chela, mesial view; E) third pereiopod, lateral view; F) fourth pereiopod, propodus and dactylus, mesial view; G) fifth pereiopod, lateral view. Paratype, male, OUMNH.ZC.2016-05-005 (cl 1.8 mm) (A-B); holotype, male, OUMNH.ZC.2016-05-001 (cl 1.8) (C-D); paratype, male, OUMNH.ZC.2016-05-004 (cl 2.7) (E-G).

First pereiopod (Fig. 3A) slender, overreaching distal margin of scaphocerite by mero-carpal articulation; merus about twice as long as ischium; carpus equal to merus in length; fingers of chelae approximately as long as palm (Fig. 3B). Second pereiopods equal in size, similar in shape (Fig. 3C), overreaching distal margin of scaphocerite by mero-carpal articulation; merus slightly longer than ischium; carpus shorter than merus, cylindrical; chelae (Fig. 3D) about 2.5 times as long as carpus; fingers straight, about 1.3 times as long as palm, cutting edges smooth, dactylus with three small blunt teeth proximally, pollex with two similar teeth proximally. 
Third pereiopod (Fig. 3E) with ischium, merus and carpus unarmed, merus about 1.6 times as long as ischium; carpus about 0.55 times as long as merus; propodus about 1.7 times as long as carpus, with 6-8 widely spaced spines along flexor margin; dactylus about 0.5 times as long as propodus, weakly biunguiculate. Fourth pereiopod (Fig. 3F) generally similar to third. Fifth pereiopod (Fig. 3G) with ischium, merus and carpus unarmed, merus about 1.8 times as long as ischium; carpus about 0.65 as long as merus; propodus about twice as long as carpus, with few widely spaced spines along flexor margin; grooming brush well-developed, consisting of four rows of 68 serrulate setae.

Telson (Fig. 1C) broad, about 1.8 times as long as wide; dorsal surface with two pairs of spines all similar in shape and size, anterior pair at about 0.35 of telson length, posterior pair at about 0.55 of telson length; posterior margin conical in shape, laterally furnished with two pairs of spines, mesial 2.5 times as long as lateral, and additionally adorned with numerous long annulate plumose setae.

Uropod (Fig. 1J) with lateral expansion on protopod; endopod and exopod subequal in length; diaeresis incomplete, with strong sharp spine laterally, adjacent to stout distolateral spine and short lateral tooth on lateral margin of exopod (Fig. 1K).

Male first pleopod (Fig. 1F) with reduced endopod; appendices internae lacking on all pleopods in males; second pleopod with well-developed appendix masculina (Fig. 1G), equal in length to endopod, with terminal tuft of four stout setae (Fig. 1H). Third to fifth pleopods similar in shape (Fig. 1I).

Etymology. The species name puteola is derived from the Latin word puteolus, meaning a small well, in reference to the habitat of the new species; used as an adjective.

Distribution. The species is only known from a single phreatic well at the type locality. Monthly sampling in five neighbouring wells and other wells in the region, near the city of Penja (to the north of Mbanga), Yabassi (to the east) and Douala (in the south) did not recover any additional specimens.

Ecology. In addition to E. puteola sp. nov., the well fauna included the oligochaete families Naididae and Haplotaxidae, and not-yet identified cyclopoid copepods and stenasellid isopods. In respect to physico-chemical parameters of the groundwater in the area, the environment is characterised by a high and stable temperature (mean minimum from $27^{\circ} \mathrm{C}$ to mean maximum $28^{\circ} \mathrm{C}$ ) and somewhat elevated acidity (mean pH values 6.32). Electrical conductivity, suspended matter, turbidity and the nutrient content of the well water were relatively low (Table 1), but similar to those of other wells of this region (Nana Nkemegni et al. 2015).

TABLE 1. Physico-chemical characteristics of groundwater from the well at Mbanga town, Cameroon.

\begin{tabular}{|c|c|}
\hline & Mean values (min-max) \\
\hline Water temperatures $\left({ }^{\circ} \mathrm{C}\right)$ & $27.2(27-28)$ \\
\hline Suspended matter (mg.L $\left.\mathrm{L}^{-1}\right)$ & $10.6(3-18)$ \\
\hline $\mathrm{pH}(\mathrm{UI})$ & $6.32(6.24-6.38)$ \\
\hline Electrical conductivity $\left(\mu \mathrm{S} . \mathrm{cm}^{-1}\right)$ & $108.6(88-122)$ \\
\hline Dissolved $\mathrm{O}_{2}(\%)$ & $73(68-78.2)$ \\
\hline $\mathrm{HCO}_{3}^{-}\left(\mathrm{mg} \cdot \mathrm{L}^{-1}\right)$ & $14.8(10.6-15.8)$ \\
\hline Calcic Harshness (mg. $\left.\mathrm{L}^{-1}\right)$ & $22(10-35)$ \\
\hline $\mathrm{NH}_{4}^{+}\left(\mathrm{mg} \cdot \mathrm{L}^{-1}\right)$ & $0.95(0.7-1.2)$ \\
\hline $\mathrm{NO}_{2}^{-}\left(\mathrm{mg} \cdot \mathrm{L}^{-1}\right)$ & $0.009(0.007-0.015)$ \\
\hline $\mathrm{NO}_{3}^{-}\left(\mathrm{mg} \cdot \mathrm{L}^{-1}\right)$ & $1.9(1.2-2.2)$ \\
\hline $\mathrm{PO}_{4}^{2-}\left(\mathrm{mg} \cdot \mathrm{L}^{-1}\right)$ & $0.52(0.47-0.55)$ \\
\hline
\end{tabular}

Discussion. The new species can easily be distinguished from the only other species in the genus, $E$. edingtonae, by the absence of the setiferous lobe on the peduncle of the eyes, which is present in E. edingtonae and was considered to be of generic value by Powell (1976). Powell (1976) also considered the shape of the scaphocerite, the absence of gills on the third maxilliped, the presence of movable spines on the merus of the ambulatory pereiopods, the unspecialised second male pleopod, the modestly developed process of the uropodal protopod and the decreasing size of the spines on the diaeresis to be characteristic for the genus. Of these, the 
presence of meral spines can no longer be considered as a genus level character, given their absence in the new species.

Further differences between both species are the lower number of spines on the lateral portion of the uropodal diaeresis (one in E. puteola vs. 2-3 in E. edingtonae); the lateral tooth of the scaphocerite falling short of the distal margin of the lamella (vs. far over reaching in E. edingtonae); the absence of a spine on the merus of the ambulatory pereiopods (present in E. edingtonae); the absence of a podobranch on the second maxilliped (present, albeit reduced in E. edingtonae) and the absence of appendices internae on the male pleopods 2-5 (present in $E$. edingtonae).

Although the species was discovered in a well, it is not clear whether it is a true stygobiont, as poorly developed facets seem to be present on the cornea of the eyes. The pigmented area of the eye appears to be very similar to that of the surface dwelling E. edingtonae, at least as illustrated by Powell (1976). Two South American species, viz. Euryrhynchus wrzesniowskii Miers, 1877 and E. burchelli Calman, 1907, were described on the basis of animals collected in phreatic wells, but have since been found to be surface water species that aside from their initial record in wells have never been found again in subterranean waters (Holthuis 1986). Thus it is possible that E. puteola is a stygophilous species rather than a true stygobiont.

\section{Acknowledgements}

C. d'Udekem d'Acoz (KBIN-IRSNB, Brussels, Belgium) is acknowledged for being instrumental in bringing this shrimp out of the darkness.

\section{References}

Cvetkov, L. (1968) Un filet phréatobiologique. Bulletin de l'Institut de Zoologie et Musée, Sofia, 22, 215-219.

CVUC-UCCC (2014) Communes et Villes Unies du Cameroun-United Councils and Cities of Cameroon). Available from: http://cvuc.cm (accessed 22 February 2017)

De Grave, S. (2007) A new species of Euryrhynchus Miers, with a discussion of the systematic position of the Euryrhynchidae Holthuis (Crustacea, Decapoda). Zoologischer Anzeiger, 246, 193-203. https://doi.org/10.1016/j.jcz.2007.06.002

Holthuis, L.B., (1950) The Palaemonidae collected by the Siboga and Snellius expeditions with remarks on other species. I. Subfamily Palaemoninae. Siboga Expedition Monographs, 39a (9), 1-268.

Holthuis, L.B. (1986) Decapoda. In: Botosaneanu, L. (Ed.), Stygofauna Mundi. A faunistic, distributional and ecological synthesis of the world fauna inhabiting subterranean waters (inclding the marine interstitial). E.J. Brill/Dr. W Backhuys, Leiden, pp. 589-615.

Ikomi, R.B. \& Arimoro, F.O. (2014) Effects of recreational activities on the littoral macroinvertebrates of Ethiope River, Niger Delta, Nigeria. Journal of Aquatic Sciences, 29, 155-170.

Ikomi, R.B., Arimoro, F.O. \& Odihirin, O.K. (2005) Composition, distribution and abundance of macroinvertebrates of the upper reaches of River Ethiope, Delta State, Nigeria. Zoologist, 3, 68-81.

Nana Nkemegni, G., Zébazé Togouet, S.H., Fomena, A., Pountougnigni, O.F. \& Piscart, C. (2015) Distribution of groundwater invertebrates in a tropical mountain climates; the case of the Bamoun tableland of the West region of Cameroon. African Journal of Aquatic Science, 40, 393-401. https://doi.org/10.2989/16085914.2015.1113922

Ogbeibu, A.E. \& Oribhabor, B.J. (2002) Ecological impact of river impoundment using benthic macro-invertebrates as indicators. Water Research, 36, 2427-2436. https://doi.org/10.1016/S0043-1354(01)00489-4

Olomukoro, J.O. (2009) Disturbance of the macroinvertebrate communities of bank-root biotope of a river in southern Nigeria. Toxicological \& Environmental Chemistry, 91, 305-314. https://doi.org/10.1080/02772240801990668

Olomukoro, J.O. \& Dirisu, A.R. (2014) Status and the diversity of macrobenthos of Udu-Ghievwen wetlands in the Niger River Delta, Nigeria. Journal of Natural Sciences Research, 4, 1-6.

Powell, C.B. (1976) Two new freshwater shrimps from West Africa: the first euryrhynchinids (Decapoda Palaemonidae) reported from the Old World. Revue de Zoologie Africaine, 90, 883-902.

Rodier, J., Legube, B. \& Merlet, N. (2009) L'analyse de l'eau. Dunod Publ., Paris, 1384 pp.

Segalen, P. (1985) Les sols et la géomorphologie du Cameroun. Cahiers O.R.S.T.O.M., série Pédologie, 5, 137-187.

Victor, R. \& Ogbeibu, A.E. (1985) Macrobenthic invertebrates of a stream flowing through farmlands in southern Nigeria. Environmental Pollution, Series A, 39, 337-349. 